\title{
Effect of Bacillus megaterium Biofilm and its Metabolites at Various Concentration Biodiesel on the Corrosion of Carbon Steel Storage Tank
}

\author{
Yustina M Pusparizkita ${ }^{1,2}$, Ardiyan Harimawan ${ }^{1}$, Hary Devianto ${ }^{1}$, Tjandra Setiadi ${ }^{1,3}$ \\ 1 Department of Chemical Engineering, Faculty of Industrial Technology, Institut Teknologi Bandung, Labtek X Jl. Ganesa, \\ Bandung 40132, Indonesia; \\ 2 Department of Environmental Engineering, Faculty of Engineering, Diponegoro University, Jl. Prof. Soedharto SH \\ Tembalang, Semarang 50275, Indonesia; \\ 3 Centre for Environmental Studies (PSLH), Institut Teknologi Bandung, Jl. Sangkuriang 42 A, Bandung 40135, Indonesia; \\ * Correspondence: ympusparizkita@lecturer.undip.ac.id (Y.M.P.);
}

Scopus Author ID 57201338677

Received: 19.08.2021; Revised: 30.09.2021; Accepted: 3.10.2021; Published: 21.10.2021

\begin{abstract}
Microorganisms in biodiesel storage tanks may generate bio-corrosion due to their hygroscopic and susceptible fuel degradation. The organisms, including Bacillus megaterium present in the hydrocarbons, resulted from the EPS and metabolites processes that subsequently control the corrosion process of the tank. This present study examined the effect of biodiesel concentration on microbial activity through TPC analyzing growth for B. megaterium. Furthermore, this study investigated EPS formation and acid metabolites production by B. megaterium based on SEM observations and acidimetric titration. Meanwhile, this study investigated the microorganism-induced corrosion impact based on gravimetric analysis. The results explained a higher biodiesel concentration in diesel oil promoted an increase in the growth of B. megaterium and the corrosion rate. Conversely, the acid metabolites produced from bacteria under the biofilm did not significantly increase the corrosion rate. Corrosion products resulting from the B. megaterium activity on the surface of the steel included Iron (II, III) oxide $\left(\mathrm{Fe}_{2} \mathrm{O}_{3}\right.$ and $\left.\mathrm{Fe}_{3} \mathrm{O}_{4}\right)$. The formation of oxide and pitting may control the strength of the surface tank in the course of biofuel storage, which may lead to the failure of the material.
\end{abstract}

Keywords: bio-corrosion; biofilm; Bacillus; biodiesel; metabolites.

(C) 2021 by the authors. This article is an open-access article distributed under the terms and conditions of the Creative Commons Attribution (CC BY) license (https://creativecommons.org/licenses/by/4.0/).

\section{Introduction}

Fossil fuel or biofuel is commonly stored in storage tanks in a given period. For this purpose, most hydrocarbon storage tanks are made of a material such as carbon steel because of their high strength and good formability. Nevertheless, carbon steel is susceptible to biocorrosion under the influence of microorganisms present in hydrocarbon fuels. Particularly, biocorrosion processes at a metal surface favorably occur in aqueous environments of waste treatment facilities, including chemical and underground pipelines transporting oil and gas [14]. In this case, biocorrosion of carbon steel storage, distribution, and infrastructure systems has significant economic impacts on maintenance costs and reduction of the fuel quality resulting from deterioration [5-8].

Further, biodiesel primarily comprises methyl esters of fatty acids (FAME) resulting from plant oils or animal fats' transesterification. This fuel is then blended with diesel fuel at varying concentrations. Biodiesel as a mixture with diesel fuel interacts with the metal surfaces 
during the storage, thereby promoting biocorrosion in the storage tanks. Compared to diesel oil, biodiesel also has a higher susceptibility to degradation by microorganisms, which has become crucial during storage [9-14]. Specifically, biodiesel's chemical composition may vary greatly depending on the raw material used [15]. Incorrect handling and storage practices of biodiesel and diesel-biodiesel blends can lead to microbial development, impacting its final quality [16]. Biodiesel also contains more dissolved oxygen than diesel oil [17,18], reducing oxidative stability and increasing fuel biodegradation $[19,20]$. In its place, it is naturally more hygroscopic than diesel oil, resulting in the mixture containing more water [21,22]. Particularly, water in the fuel becomes a habitat for the metabolism and growth of microorganisms [15,23].

Correspondingly, biodiesel may be contaminated by microorganisms because the storage tank's condition is difficult to keep sterile. In contrast, microorganisms can survive in systems such as air, water, or soil [24]. Factors of climate, distribution system design, the chemical composition of fuels, methods, and effectiveness of cleaning and controlling product quality may contribute to microorganism contamination in operation and storage tanks. However, storage conditions contribute more to contamination and corrosion [25]. Accordingly, the presence of microorganisms needs controlling during biodiesel storage, in turn preventing the corrosion tank.

Recently, microorganism contamination affecting diesel and biodiesel properties has been reported for specifically biocorrosion with microorganism activity [15,22,26,27]. Here biocorrosion proceeds related to the degradation of hydrocarbons when utilized by microorganisms as carbon and energy sources [22,28,29]. Consequently, biodiesel, as a mix of diesel oil, can promote corrosion in hydrocarbon storage tanks. Instead, in Indonesia, a mixture of diesel oil contains a higher concentration of biodiesel than that of the mix found in other countries, which reaches $30 \% \mathrm{v} / \mathrm{v}$. With a relatively high mix ratio, hygroscopic biodiesel is more easily contaminated by the presence of microorganisms, making it easily degraded.

Within the storage tank, microorganisms utilize biodiesel blends as a carbon source to carry out metabolism that will induce corrosion [30,31]. Among several species, Bacillus sp. is a microorganism that dominates the biodegradation of hydrocarbon products, affecting the corrosion rate $[32,33]$. $B$. megaterium is one species identified in the corrosion products of diesel oil transportation pipelines in India, and its effect on biocorrosion was previously reported [34]. However, the way this microorganism affects corrosion is still poorly understood, particularly in systems involving biodiesel degradation and efficiency of utility by microorganisms. Principally, the biocorrosion process on the metal surface of the storage tank relates the ability of microorganisms to degrade hydrocarbons and forms a complex matrix of extracellular polymeric substances (EPS) [35] and metabolites that change the state of the surrounding environment.

The present research was undertaken to investigate the impact of $B$. megaterium microbial activities on the surface of the carbon steel tank, which controls biocorrosion containing biodiesel. In particular, several factors were considered in this study, including the growth and metabolite levels of biodiesel in this species and the carbon steel tanks' corrosion rate. Results are expected to add knowledge on preventing the biocorrosion of the storage tanks.

\section{Materials and Methods}

The immersed environment was prepared with a blend of biodiesel and diesel. In this case, diesel fuel was blended using 15\% (B15), 20\% (B20), 30\% (B30) v/v biodiesel, and 100\% 
(B100) pure biodiesel, herewith presented in this paper as a mixture of B15, B20, B30, and B100. The biofuel was provided by PT. Darmex Agro, while the commercial fuel of diesel, was purchased at the Pertamina gas station. Subsequently, the medium was filtered through the CA filter membrane using $0.45 \mu \mathrm{m}$ pores before experiments of biocorrosion.

The microorganism of Bacillus megaterium was obtained from the National University of Singapore. This bacterial was then treated in several stages. They were firstly cultured in $250 \mathrm{ml}$ Erlenmeyer filled with $100 \mathrm{ml}$ sterilized Bushnell Haas (BH) medium until the beginning of the stationary phase. $2 \mathrm{ml}$ inoculated bacteria were taken into $500 \mathrm{ml}$ Erlenmeyer containing $300 \mathrm{ml}$ of $\mathrm{BH}$ medium and $1 \mathrm{~g}$ of sterilized diesel oil as sole nutrition. The bacteria were then incubated in a rotary shaker with a temperature of $30^{\circ} \mathrm{C}$ and $150 \mathrm{rpm}$ for 22 days (x10 $\left.0^{6} \mathrm{CFU} / \mathrm{ml}\right)$.

Carbon steel ST-37, commonly used for a storage tank, was prepared as a coupon of specimens for corrosion observation. The carbon steel was then cut into pieces with a size of 1 $\mathrm{cm} \times 1 \mathrm{~cm}$. Immersion was carried out based on the ASTM G 31-72 standard with a size of $0.025-0.050 \mathrm{~cm} 2$ for $1 \mathrm{ml}$ of the test solution. Subsequently, the test solution's volume was 200 $\mathrm{ml}$ so that the maximum surface area of the steel plate was $10 \mathrm{~cm}^{2}$ per reactor. After that, the coupons were polished with 240-1200 grid abrasive paper, according to ASTM G 1-90. All the specimens were then cleaned with demineralized water and ethanol to remove fat and impurities after polishing. Eventually, they were dried with an electric dryer and stored in a desiccator before material characterization.

Bio-corrosion processes on the surface of the tank were investigated by carrying out storage simulations, in which the carbon steel coupons were immersed in the medium for 20 days. The immersion was carried out in a $250 \mathrm{ml}$ glass reactor with a $200 \mathrm{ml}$ working volume consisting of medium and $10 \% \mathrm{v} / \mathrm{v}$ bacteria on $\mathrm{BH}$ solution, which has passed the acclimatization process. The soaking process was done at a temperature of $30^{\circ} \mathrm{C}$ and under anaerobic conditions, similar to the process in the storage tank for 20 days.

TPC (Total Plate Count) with the spread plate method was carried out to determine the number of B. megaterium living in biofilms formed on metal surfaces. The attached biofilm was removed from the metal surface and dissolved in $10 \mathrm{ml}$ of demining water. The sample was then diluted with a dilution factor of up to 10,000 times. $0.1 \mathrm{ml}$ was taken and distributed to the nutrient agar (NA), hardened in a petri dish from each dilution result. Petri dishes containing microbes were stored in an incubator of $30^{\circ} \mathrm{C}$, and the calculation of the number of colonies was carried out after two days of storage. This analysis was carried out every five days during the immersion period.

Acidimetric titration was carried out to quantify the concentration of metabolites produced by $B$. megaterium in biofilms formed on the metal surfaces. This analysis can prove the effect of metabolites produced on metal corrosion.

SEM SU3500-Hitachi Ltd, Tokyo, Japan, at various magnifications, were used to observe the biofilm formed on the samples, obtained by immersing in formal aldehyde of a phosphate buffer with a $\mathrm{pH}$ of 7.3 for 24 hours. For this reason, samples were then rinsed with demineralized water and followed by ethanol at concentrations of 20\%, 50\%, 75\%, and 98\%. The coupon was dried with an electric dryer and stored in a desiccator before SEM examination.

The gravimetric procedure was carried out to determine the specimen's corrosion rate according to ASTM G 1-03. In this way, the biofilm-free metal coupons were soaked in a $6 \mathrm{~N}$ $\mathrm{HCl}$ solution containing 20 grams of $\mathrm{Sb}_{2} \mathrm{O}_{3}$ and 50 grams of $\mathrm{SnCl}_{2}$ for 1-25 minutes to remove 
corrosion products. Metal coupons were then rinsed with demineralized water, dipped in ethanol, and dried with an electric dryer, and weighed. The rinsing and drying processes were repeated until a constant metal weight was obtained.

The metal corrosion products were analyzed using XRD following ASTM A751. Initially, metal coupons for XRD measurement were prepared by removing biofilm. Then, they were dipped in ethanol and dried. Analysis of corrosion products was carried out on the 20thday samples. Moreover, the microstructure of corrosion products and the corrosion damage were observed using SEM SU3500 (Hitachi Ltd, Tokyo, Japan).

\section{Results and Discussion}

Profiles of B. megaterium colonies based on TPC analysis are presented in Figure 1. In the mixture fuel of B15, the number of colonies seemed to grow until it reached $232.5 \times 10^{5}$ $\mathrm{CFU} / \mathrm{cm}^{2}$ on the 20th day. Obviously, the average number of colonies continued increasing until the end of the immersion showing that microorganisms could still be in the exponential growth phase. In the B20 fuel, however, the number of colonies continued to increase, reaching $450 \times 10^{5} \mathrm{CFU} / \mathrm{cm}^{2}$ on the fifth day and then decreasing to $102.5 \times 10^{5} \mathrm{CFU} / \mathrm{cm}^{2}$. The same living colony profiles could be shown in fuels of B30 and B100. The number of colonies tended to increase until the fifth day and reached $537.5 \times 10^{5} \mathrm{CFU} / \mathrm{cm}^{2}$ for the $\mathrm{B} 30$ mixture and 687.5 x $10^{5} \mathrm{CFU} / \mathrm{cm}^{2}$ for the B100 mixture. After the fifth day, the number of living colonies decreased until the end of the soaking time. The maximum number of colonies reached on the fifth day for the mixtures of $\mathrm{B} 20, \mathrm{~B} 30$, and $\mathrm{B} 100$ shows that $\mathrm{B}$. megaterium has reached a stationary growth phase. On the fifth day of immersion, the effect of biodiesel concentration on the growth of $B$. megaterium was also significant. The average number of colonies in biofilms increased in line with the biodiesel concentration, which is $107.5 \times 10^{5} \mathrm{CFU} / \mathrm{cm}^{2}$ for $\mathrm{B} 15,450 \times 10^{5} \mathrm{CFU} / \mathrm{cm}^{2}$ for B20, $537.5 \times 10^{5} \mathrm{CFU} / \mathrm{cm}^{2}$ for B30 and $687.5 \times 10^{5} \mathrm{CFU} / \mathrm{cm}^{2}$ for B100, respectively.

Further, the presence of biodiesel in diesel oil affected microbial growth. The average number of $B$. megaterium living colonies seemed to change in the different biodiesel concentrations for 20 days of immersion. With the B15 mixture, the average number of living colonies reached $129 \times 10^{5} \mathrm{CFU} / \mathrm{cm}^{2}$. The average number of living colonies increased in the B20 mixture of $197 \times 10^{5} \mathrm{CFU} / \mathrm{cm}^{2}$, B30 $353 \times 10^{5} \mathrm{CFU} / \mathrm{cm}^{2}$, and $433.5 \times 10^{5} \mathrm{CFU} / \mathrm{cm}^{2}$ in the B100 mixture since biodiesel is more susceptible to biodeterioration than diesel oil. The molecules in biodiesel are subjected to be degraded by microorganisms. In addition to utilizing biodiesel as a substrate, microorganisms do not require special abilities [9,36-39]. The hygroscopic nature of biodiesel compared to diesel oil also controls microorganisms' high activity and growth [18]. Importantly, the water trapped in the fuel becomes the habitat of microorganisms for a significant role in the metabolism and growth of microbes $[23,40]$. By consuming biodiesel, microorganisms form biofilms to store the nutrients needed to maintain the metabolic process [30].

Correspondingly, the number of colonies seemed to decrease after the fifth day on respective fuel mixtures of $\mathrm{B} 20, \mathrm{~B} 30$, and $\mathrm{B} 100$, when microorganisms started entering the phase of death, and biofilms underwent a lysis process. Also, the number of nutrients decreased, causing microbes initially trapped in biofilms to be released into the solution for forming new colonies elsewhere [41].

Furthermore, the decrease in the number of colonies may result from microorganisms producing metabolites. As long as microorganisms grow and multiply, in addition to EPS 
making a constituent of biofilms, acid metabolites can be made. Under conditions of lack of oxygen (acting as electron acceptors) as in the bottom of the storage tank, fermentation occurred due to microbial metabolism in the water phase. This process leads to the production of organic acids [12,42,43]. Accordingly, an increase in biodiesel concentration for microorganisms' metabolism influenced metabolites' output, including acid metabolites. Subsequently, the concentration of acid metabolites was quantified by B. megaterium using the acidimetric titration method, and the result is shown in Figure 1.

B15

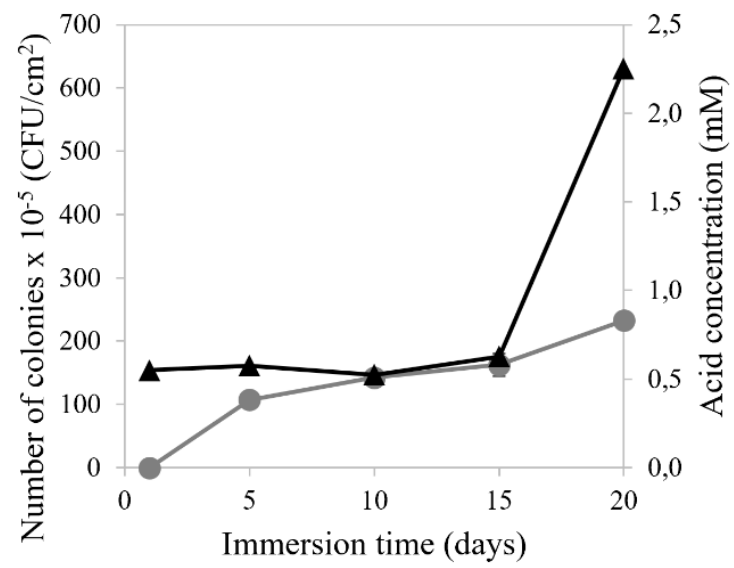

B30

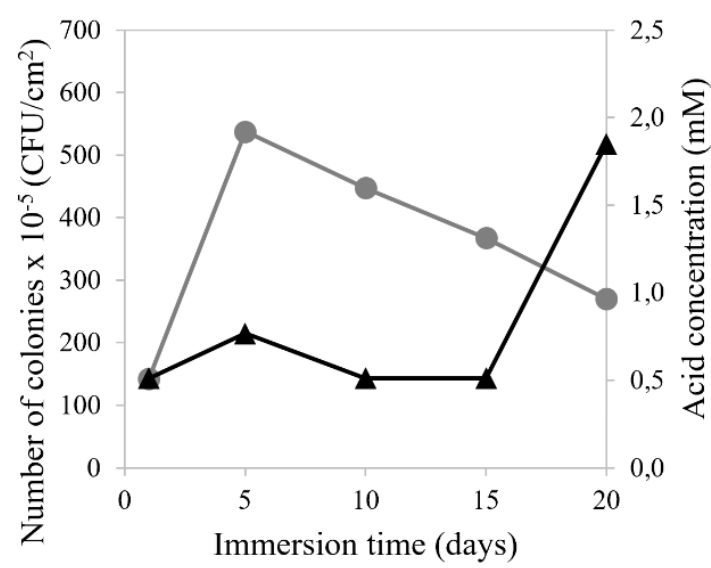

B20

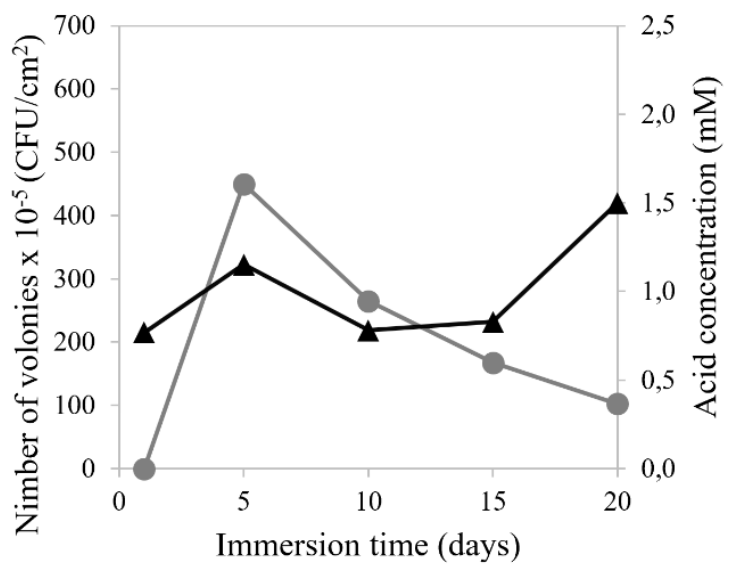

$\mathrm{B} 100$

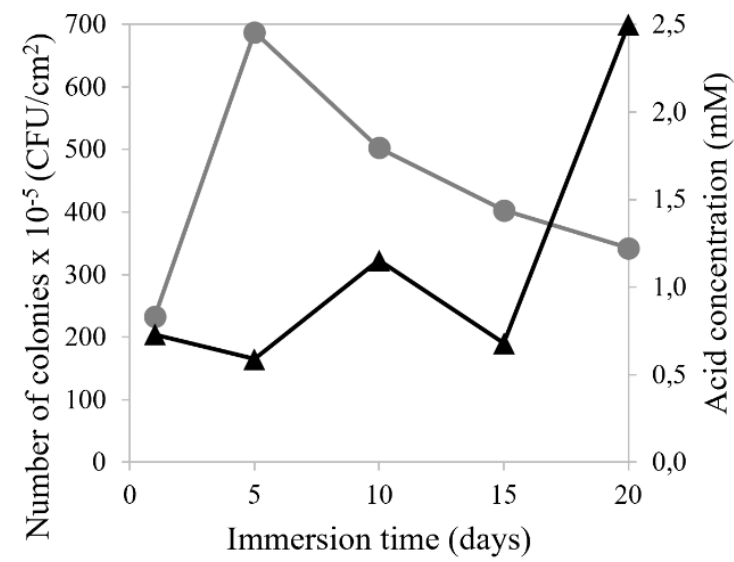

Figure 1. The number of B. megaterium colonies and the concentration of acid in the biofilm.

The concentration of biodiesel influenced the acid metabolites produced by $B$. Megaterium (Figure 1). Consequently, the concentration of acid metabolites accumulating at the end of the immersion time is more likely to increase along with the increasing percentage of biodiesel in diesel oil, which is $1.5 \mathrm{mM}$ for B20; $1.85 \mathrm{mM}$ for B30, and $2.5 \mathrm{mM}$ for B100. However, acid metabolites trapped in biofilms could be toxic to microorganisms, so that the number of living colonies on metal surfaces was reduced as found in the fuel mixtures of B20, B30, and B100. Due to microorganisms still in the growth phase, acid concentrations reached $2.25 \mathrm{mM}$ for $\mathrm{B} 15$ at the end of the immersion time. For other biodiesel mixtures, microorganisms have entered the stage of death or spread due to lysis events.

Further growth activity, biofilm formation, and acid metabolite production by $B$. megaterium made an increase in biodiesel concentrations affecting carbon steel corrosion. Here, the corrosion rate is known as the corrosion parameter to describe the kinetics of a metal's corrosion reaction in an environment. For this purpose, the corrosion rate was determined by the gravimetric analysis method or based on metal mass loss. The result shows that the 
corrosion rate of carbon steel is controlled by biodiesel concentration and the activity of $B$. megaterium (Figure 2).

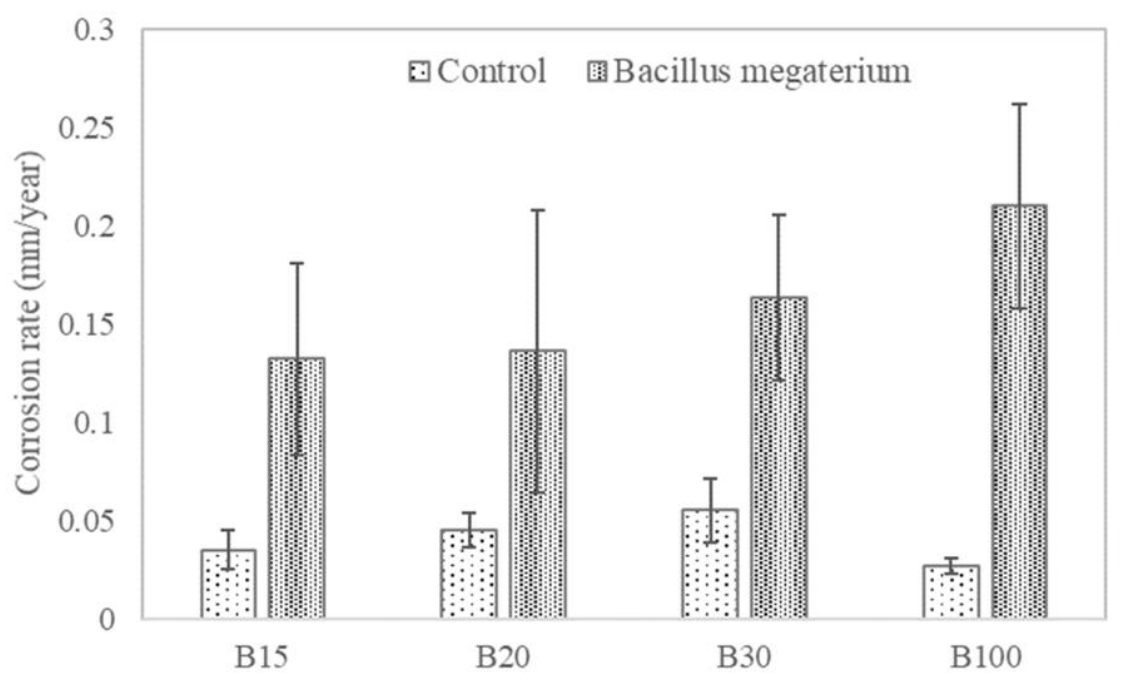

Figure 2. Effect of B. megaterium activities on the corrosion of carbon steel.

This was also confirmed by the results of the ANOVA statistical analysis with a $\mathrm{P}$ value $<0.05$. With the mixture of B15, the average metal corrosion rate reached $0.132 \pm 0.049$ $\mathrm{mm} /$ year. Although it was not very significant, an increase in the corrosion rate occurred in the mixture of B20 in the order of $0.136 \pm 0.072 \mathrm{~mm} / \mathrm{year}$. In the higher biodiesel concentration (B30), metals' corrosion rate reached $0.163 \pm 0.042 \mathrm{~mm} / \mathrm{year}$, whereas, in the B100 medium, the corrosion rate of metals was achieved by $0.210 \pm 0.052 \mathrm{~mm} /$ year. The highest average corrosion rate in the B100 mixture proved that biodiesel has the property of being easily oxidized or degraded so that B. megaterium can use it as a carbon source.

The presence of B. megaterium in the diesel-biodiesel oil medium made an increase in the corrosion rate of carbon steel compared to the sterile medium (Figure 2). However, in the absence of microorganisms (control), corrosion rates with increasing biodiesel concentrations were apparent. This is due to the hygroscopic nature of biofuels. The nature of biodiesel, which easily absorbs water from the atmosphere and has more excellent water solubility than fossil fuels, allows for water accumulation. Besides, high humidity can affect the absorption of water by biodiesel. Biodiesel can absorb water up to $1200 \mathrm{ppm}$ under 95\% humidity [44].

Also, biodiesel's water content can affect the corrosion rate [45,46]. Also, water in biodiesel can cause oxidation events and produce corrosive oxidation products in aldehydes, alcohols, and short-chain carboxylic acids $[47,48]$. Correspondingly, the decrease in corrosion rate in the B100 mixture in the absence of microorganism activity is due to the formation of a passive layer resulting from the reaction between dissolved oxygen, in the amounts from 10$20 \% \mathrm{v} / \mathrm{v}$ on biodiesel and the metal surface. This research demonstrated that the mixing process between diesel oil and biodiesel leads to carbon steel corrosion even though, according to ElAraby et al. [49], biodiesel blends up to B30 have the main characteristics of fuel which are not much different from diesel oil in terms of density, kinematic viscosity, and flashpoint. This can be caused when biodiesel is added to diesel oil, the biodegradability of the fuel mixture will increase [50].

Biodiesel concentration, B. megaterium activity, and metal immersion time can also contribute to metal corrosion rate. However, in this study, the concentration of biodiesel and immersion time did not have a combined effect on the rate of metal corrosion.B. megaterium 
activity on the surface of carbon steel in a mixture of biodiesel and diesel oil caused corrosion damage in the form of pitting (Figure 3). Here magnetite and hematite were formed on the metal's surface as corrosion products (Figure 4). Besides, corrosion on metal surfaces can occur when the interaction between $B$. megaterium and medium produces acidic metabolic products. In biofilms, these metabolite products may be corrosive and affect the formation of pitting on metals $[24,45,51]$. The corrosion process may also be related to organic acid production during fermentative or aerobic metabolism [12]. However, in a mixture of biodiesel and diesel oil, acid produced by $B$. megaterium has a lower effect on carbon steel's corrosion rate. This can be seen from the high acid concentration at the end of the immersion period, not followed by an increase in metal corrosion rate (Figure 5). In this system, biofilms on metal surfaces contribute more to the metal corrosion rate. Despite chemical corrosion being the most frequently described, studies show the participation of microorganisms in direct corrosion processes or the acceleration/influence of the corrosive action through the formation of complex biofilms [51,52].

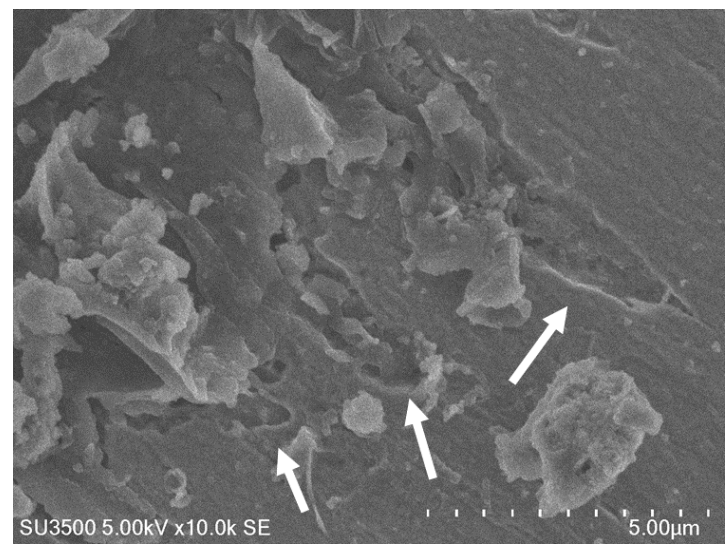

Figure 3. Pitting corrosion on the carbon steel.

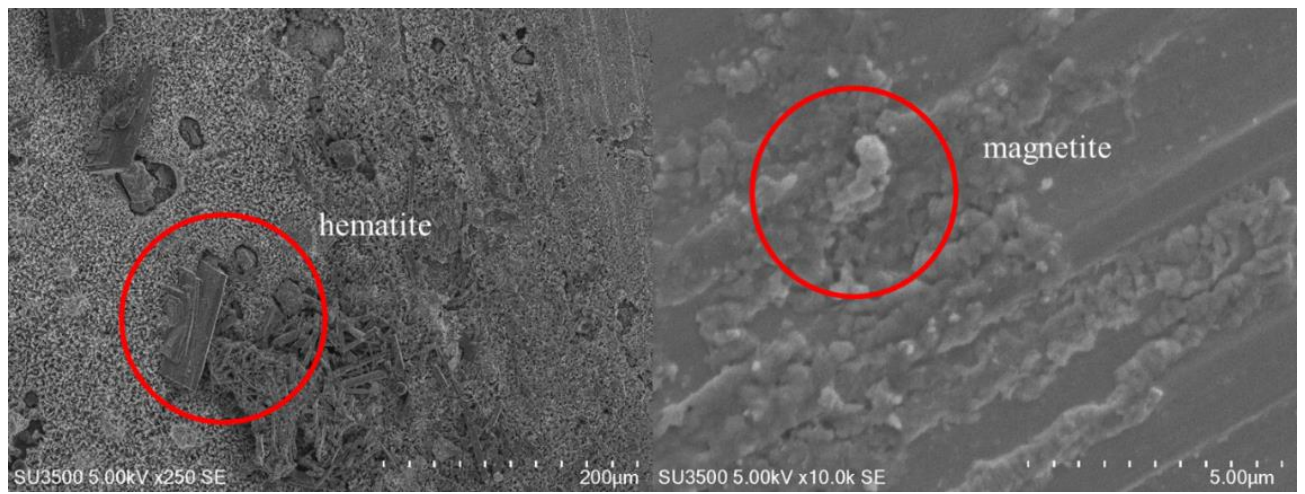

Figure 4. Corrosion products on the carbon steel surface.

Further, biofilms may create different environmental conditions, such as differences in dissolved oxygen. The area covered by biofilm will act as the anode side in the event of corrosion. The oxidation reaction on the anode side produces electrons that will move to the cathode side. The more surfaces without biofilm, the more electrons must be provided from the area under the biofilm for the redox reaction to proceed. Therefore, corrosion in the form of pitting will be formed. 
B15

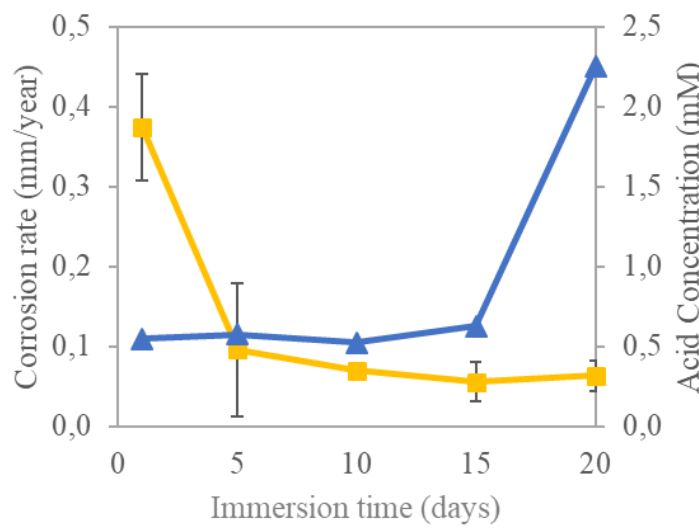

B30

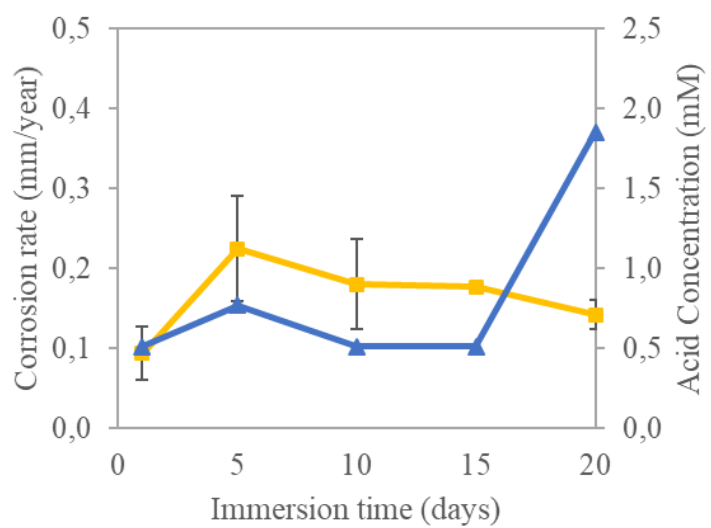

B20

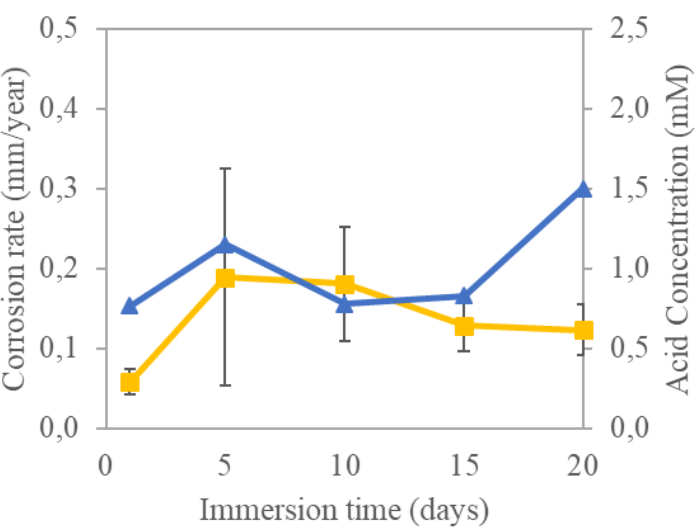

B100

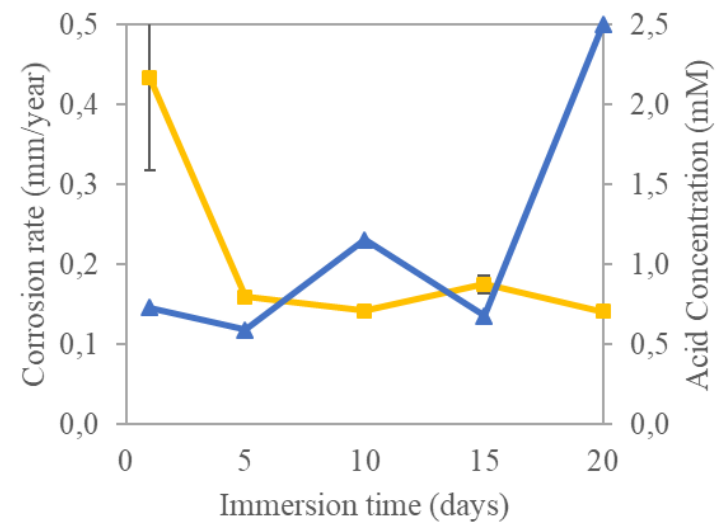

Corrosion rate $\simeq$ Acid

Figure 5. Corrosion rate and acid concentration with the presence of B. megaterium.

\section{Conclusions}

It can be concluded that the biodiesel concentration and immersion time affected the growth of $B$. megaterium on biofilm, metabolites concentration, and carbon steel corrosion rate. The higher the biodiesel concentration in the medium, the average growth of $B$. megaterium and acid metabolites in biofilms increased. Also, this activity influenced the corrosion rate of carbon steel. However, the corrosion rate in this system was influenced not only by $B$. megaterium but also by the medium. The effect of environmental differences due to biofilms by $B$. megaterium plays a more significant role in this system than the metabolites. The impact of $B$. megaterium resulted in pitting corrosion, corrosion products of magnetite and hematite.

\section{Funding}

The research and study were supported by the Ministry of Research, Technology, and Higher Education (DIKTI) Indonesia through PMDSU [grant number 128/SP2H/PTNBH/DRPM/2018] scholarship.

\section{Acknowledgments}

The authors would like to thank Steven, Imelda, Dr. Isdiriayani Nurdin, Dr. Pramujo Widiatmoko, Dewi Puspitasari Effendi, RatnaWindari, and Wahyu Ruhimat for their support and assistance in the experiment. 


\section{Conflicts of Interest}

The authors declare no conflict of interest. The funders had no role in the design of the study, in the collection, analyses, or interpretation of data, in the writing of the manuscript, or in the decision to publish the results.

\section{References}

1. Jia, R.; Yang, D.; Xu, D.; Gu, T. Electron Transfer Mediators Accelerated the Microbiologically Influence Corrosion against Carbon Steel by Nitrate Reducing Pseudomonas Aeruginosa Biofilm. Bioelectrochemistry 2017, 118, 38-46, https://doi.org/10.1016/j.bioelechem.2017.06.013.

2. Wikieł, A.J.; Datsenko, I.; Vera, M.; Sand, W. Impact of Desulfovibrio Alaskensis Biofilms on Corrosion Behaviour of Carbon Steel in Marine Environment. Bioelectrochemistry 2014, 97, 52-60, https://doi.org/10.1016/j.bioelechem.2013.09.008.

3. Liu, D.; Yang, H.; Li, J.; Li, J.; Dong, Y.; Yang, C.; Jin, Y.; Yassir, L.; Li, Z.; Hernandez, D.; Xu, D.; Wang, F.; Smith, J.A. Electron transfer mediator PCN secreted by aerobic marine Pseudomonas aeruginosa accelerates microbiologically influenced corrosion of TC4 titanium alloy. Journal of Materials Science \& Technology 2021, 79, 101-108, https://doi.org/10.1016/j.jmst.2020.11.042.

4. Chen, S.; Deng, H.; Zhao, Y.; Lu, S.; Zhao, Y.; Cheng, X.; Liu, G.; Dou, W.; Chen, J. The Effects of Methanococcus Maripaludis on the Corrosion Behavior of EH40 Steel in Seawater. Bioelectrochemistry 2021, 140, https://doi.org/10.1016/j.bioelechem.2021.107824.

5. Suflita, J.M.; Lyles, C.N.; Aktas, D.F.; Sunner, J. 12 - Biocorrosion issues associated with the use of ultralow sulfur diesel and biofuel blends in the energy infrastructure. In: Understanding Biocorrosion. Woodhead Publishing: Oxford, 2014; pp. 313-328, https://doi.org/10.1533/9781782421252.3.313.

6. Kannan, P.; Su, S.S.; Mannan, M.S.; Castaneda, H.; Vaddiraju, S. A Review of Characterization and Quantification Tools for Microbiologically Influenced Corrosion in the Oil and Gas Industry: Current and Future Trends. Ind. Eng. Chem. Res. 2018, 57, 13895-13922, https://doi.org/10.1021/acs.iecr.8b02211.

7. Su, H.; Mi, S.; Peng, X.; Han, Y. The Mutual Influence between Corrosion and the Surrounding Soil Microbial Communities of Buried Petroleum Pipelines. RSC Adv. 2019, 9, 18930-18940, https://doi.org/10.1039/C9RA03386F.

8. Dahal, K.P.; Timilsena, J.N.; Gautam, M.; Bhattarai, J. Investigation on Probabilistic Model for Corrosion Failure Level of Buried Pipelines in Kirtipur Urban Areas (Nepal). Journal of Failure Analysis and Prevention 2021, 21, 914-926, https://doi.org/10.1007/s11668-021-01138-2.

9. Aktas, D.F.; Lee, J.S.; Little, B.J.; Duncan, K.E.; Perez-Ibarra, B.M.; Suflita, J.M. Effects of Oxygen on Biodegradation of Fuels in a Corroding Environment. International Biodeterioration \& Biodegradation 2013, 81, 114-126, https://doi.org/10.1016/j.ibiod.2012.05.006.

10. Bücker, F.; Barbosa, C.S.; Quadros, P.D.; Bueno, M.K.; Fiori, P.; Huang, C. te; Frazzon, A.P.G.; Ferrão, M.F.; de Oliveira Camargo, F.A.; Bento, F.M. Fuel Biodegradation and Molecular Characterization of Microbial Biofilms in Stored Diesel/Biodiesel Blend B10 and the Effect of Biocide. International Biodeterioration \& Biodegradation 2014, 95, 346-355, https://doi.org/10.1016/j.ibiod.2014.05.030.

11. Ławniczak, Ł.; Woźniak-Karczewska, M.; Loibner, A.P.; Heipieper, H.J.; Chrzanowski, Ł. Microbial Degradation of Hydrocarbons-Basic Principles for Bioremediation: A Review. Molecules 2020, 25, https://doi.org/10.3390/molecules25040856.

12. Stamps, B.W.; Bojanowski, C.L.; Drake, C.A.; Nunn, H.S.; Lloyd, P.F.; Floyd, J.G.; Emmerich, K.A.; Neal, A.R.; Crookes-Goodson, W.J.; Stevenson, B.S. In Situ Linkage of Fungal and Bacterial Proliferation to Microbiologically Influenced Corrosion in B20 Biodiesel Storage Tanks. Frontiers in Microbiology 2020, 11, https://doi.org/10.3389/fmicb.2020.00167.

13. Cardeño, F.; Lapuerta, M.; Rios, L.; Agudelo, J.R. Reconsideration of Regulated Contamination Limits to Improve Filterability of Biodiesel and Blends with Diesel Fuels. Renewable Energy 2020, 159, 1243-1251, https://doi.org/10.1016/j.renene.2020.06.079.

14. Fernandes, D.M.; Squissato, A.L.; Lima, A.F.; Richter, E.M.; Munoz, R.A.A. Corrosive Character of Moringa Oleifera Lam Biodiesel Exposed to Carbon Steel under Simulated Storage Conditions. Renewable Energy 2019, 139, 1263-1271, https://doi.org/10.1016/j.renene.2019.03.034.

15. Cavalcanti, E.H. [de S.; Zimmer, A.R.; Bento, F.M.; Ferrão, M.F. Chemical and Microbial Storage Stability Studies and Shelf Life Determinations of Commercial Brazilian Biodiesels Stored in Carbon Steel Containers in Subtropical Conditions. Fuel 2019, 236, 993-1007, https://doi.org/10.1016/j.fuel.2018.09.043.

16. Ribas, R.; Cazarolli, J.C.; da Silva, E.C.; Meneghetti, M.R.; Meneghetti, S.M.P.; Bento, F.M. Characterization of Antimicrobial Effect of Organotin-Based Catalysts on Diesel-Biodiesel Deteriogenic Microorganisms. Environmental Monitoring and Assessment 2020, 192, https://doi.org/10.1007/s10661-02008744-x. 
17. Singh, D.; Sharma, D.; Soni, S.L.; Sharma, S.; Kumari, D. Chemical Compositions, Properties, and Standards for Different Generation Biodiesels: A Review. Fuel 2019, 253, 60-71, https://doi.org/10.1016/j.fuel.2019.04.174.

18. Sørensen, G.; Pedersen, D.V.; Nørgaard, A.K.; Sørensen, K.B.; Nygaard, S.D. Microbial Growth Studies in Biodiesel Blends. Bioresource Technology 2011, 102, 5259-5264, https://doi.org/10.1016/j.biortech.2011.02.017.

19. Speidel, H.K.; Lightner, R.L.; Ahmed, I. Biodegradability of New Engineered Fuels Compared to Conventional Petroleum Fuels and Alternative Fuels in Current Use. Appl Biochem Biotechnol 2000, 84-86, 879-897, https://doi.org/10.1007/978-1-4612-1392-5_69.

20. Mathew, G.M.; Raina, D.; Narisetty, V.; Kumar, V.; Saran, S.; Pugazhendi, A.; Sindhu, R.; Pandey, A.; Binod, P. Recent Advances in Biodiesel Production: Challenges and Solutions. Science of The Total Environment 2021, 794, https://doi.org/10.1016/j.scitotenv.2021.148751.

21. Fregolente, P.B.L.; Fregolente, L.V.; Wolf Maciel, M.R. Water Content in Biodiesel, Diesel, and BiodieselDiesel Blends. J. Chem. Eng. Data 2012, 57, 1817-1821, https://doi.org/10.1021/je300279c.

22. Cazarolli, J.C.; Silva, T.L.; Lobato, M.R.; Brito, J.R.d.; Rampelotto, P.H.; Rocha, J.V.d.S.; Azambuja, A.O.d.; Mann, M.B.; Ferrão, M.F.; Peralba, M.d.C.R.; Martinelli, M.; Frazzon, A.P.G.; Frazzon, J.; Quadros, P.D.d.; Camargo, F.A.d.O.; Bento, F.M. Impact of water content on microbial growth in Brazilian biodiesel during simulated storage. Fuel 2021, 297, https://doi.org/10.1016/j.fuel.2021.120761.

23. Ramadhani, A.N.; Harimawan, A.; Devianto, H. Water Content Effect on Biofilm Formation and BioCorrosion Process in Biodiesel-Diesel Storage Tank. International journal of engineering and technology 2018, 7, 2009-2012, https://doi.org/10.14419/ijet.v7i4.15592.

24. Lee, J.S.; Ray, R.I.; Little, B.J. An Assessment of Alternative Diesel Fuels: Microbiological Contamination and Corrosion under Storage Conditions. Biofouling 2010, 26, 623-35, https://doi.org/10.1080/08927014.2010.504984.

25. Komariah, L.N.; Arita, S.; Prianda, B.E.; Dewi, T.K. Technical Assessment of Biodiesel Storage Tank; A Corrosion Case Study. Journal of King Saud University - Engineering Sciences 2021, https://doi.org/10.1016/j.jksues.2021.03.016.

26. Menezes Bento, F.; Beech, I.B.; Gaylarde, C.C.; Englert, G.E.; Muller, I.L. Degradation and Corrosive Activities of Fungi in a Diesel-Mild Steel-Aqueous System. World Journal of Microbiology and Biotechnology 2005, 21, 135-142, https://doi.org/10.1007/s11274-004-3042-2.

27. M. Bento, F.; C. Gaylarde, C. Biodeterioration of Stored Diesel Oil: Studies in Brazil. International Biodeterioration \& Biodegradation 2001, 47, 107-112, https://doi.org/10.1016/S0964-8305(00)00112-8.

28. Aktas, D.F.; Lee, J.S.; Little, B.J.; Ray, R.I.; Davidova, I.A.; Lyles, C.N.; Suflita, J.M. Anaerobic Metabolism of Biodiesel and Its Impact on Metal Corrosion. Energy Fuels 2010, 24, 2924-2928, https://doi.org/10.1021/ef100084j.

29. Horel, A.; Schiewer, S. Microbial Degradation of Different Hydrocarbon Fuels with Mycoremediation of Volatiles. Microorganisms 2020, 8, https://doi.org/10.3390/microorganisms8020163.

30. Pusparizkita, Y.M.; Schmahl, W.; Setiadi, T.; Ilsemann, B.; Reich, M.; Devianto, H.; Harimawan, A. Evaluation of Bio-Corrosion on Carbon Steel by Bacillus Megaterium in Biodiesel and Diesel Oil Mixture. Journal of Engineering and Technological Sciences 2020, 52.

31. Pusparizkita, Y.M.; Setiadi, T.; Harimawan, A. Effect of Biodiesel Concentration on Corrosion of Carbon Steel by Serratia Marcescens. MATEC Web Conf. 2018, 156, https://doi.org/10.1051/matecconf/201815601008.

32. Elumalai, P.; Parthipan, P.; Narenkumar, J.; Anandakumar, B.; Madhavan, J.; Oh, B.-T.; Rajasekar, A. Role of Thermophilic Bacteria (Bacillus and Geobacillus) on Crude Oil Degradation and Biocorrosion in Oil Reservoir Environment. 3 Biotech 2019, 9, https://doi.org/10.1007/s13205-019-1604-0.

33. Wang, D.; Lin, J.; Lin, J.; Wang, W.; Li, S. Biodegradation of Petroleum Hydrocarbons by Bacillus Subtilis BL-27, a Strain with Weak Hydrophobicity. Molecules 2019, https://doi.org/10.3390/molecules24173021.

34. Rajasekar, A.; Ponmariappan, S.; Maruthamuthu, S.; Palaniswamy, N. Bacterial Degradation and Corrosion of Naphtha in Transporting Pipeline. Current Microbiology 2007, 55, 374-381, https://doi.org/10.1007/s00284-007-9001-z.

35. Elumalai, P.; AlSalhi, M.S.; Mehariya, S.; Karthikeyan, O.P.; Devanesan, S.; Parthipan, P.; Rajasekar, A. Bacterial Community Analysis of Biofilm on API 5LX Carbon Steel in an Oil Reservoir Environment. Bioprocess Biosyst Eng 2021, 44, 355-368, https://doi.org/10.1007/s00449-020-02447-w.

36. Castanheira, É.G.; Grisoli, R.; Coelho, S.; Silva, G. [Anderi da; Freire, F. Life-Cycle Assessment of SoybeanBased Biodiesel in Europe: Comparing Grain, Oil and Biodiesel Import from Brazil. Journal of Cleaner Production 2015, 102, 188-201, https://doi.org/10.1016/j.jclepro.2015.04.036.

37. Khan, T.M.Y.; Atabani, A.E.; Badruddin, I.A.; Badarudin, A.; Khayoon, M.S.; Triwahyono, S. Recent Scenario and Technologies to Utilize Non-Edible Oils for Biodiesel Production. Renewable and Sustainable Energy Reviews 2014, 37, 840-851, https://doi.org/10.1016/j.rser.2014.05.064. 
38. Mahmudul, H.M.; Hagos, F.Y.; Mamat, R.; Adam, A.A.; Ishak, W.F.W.; Alenezi, R. Production, Characterization and Performance of Biodiesel as an Alternative Fuel in Diesel Engines - A Review. Renewable and Sustainable Energy Reviews 2017, 72, 497-509, https://doi.org/10.1016/j.rser.2017.01.001.

39. Onabanjo, T.; Lorenzo, G. [Di; Goodger, E.; Somorin, Y. Modelling of Microbial Fuel Degradation in Liquid Fuels for a Gas Turbine Engine Application. International Biodeterioration \& Biodegradation 2016, 109, 191-201, https://doi.org/10.1016/j.ibiod.2016.01.005.

40. Prince, R.C.; Haitmanek, C.; Lee, C.C. The Primary Aerobic Biodegradation of Biodiesel B20. Chemosphere 2008, 71, 1446-1451, https://doi.org/10.1016/j.chemosphere.2007.12.010.

41. Wang, G.; Chai, K.; Wu, J.; Liu, F. Effect of Pseudomonas Putida on the Degradation of Epoxy Resin Varnish Coating in Seawater. International Biodeterioration \& Biodegradation 2016, 115, 156-163, https://doi.org/10.1016/j.ibiod.2016.08.017.

42. Vargel, C. Chapter C.12 - Microbiologically influenced corrosion. In: Corrosion of Aluminium (Second Edition). Vargel, C. Ed.; Elsevier: Amsterdam, 2020; pp. 289-294.

43. Miller, R.B.; Sadek, A.; Crouch, A.L.; Floyd, J.G.; Drake, C.A.; Stevenson, B.S.; Crookes-Goodson, W.; Monty, C.N.; Senko, J.M. Novel Mechanism of Microbially Induced Carbon Steel Corrosion at an Aqueous/Non-Aqueous Interface. Ind. Eng. Chem. Res. 2020, 59, 15784-15790, https://doi.org/10.1021/acs.iecr.0c02497.

44. He, B.B.; Thompson, J.C.; Routt, D.W.; Gerpen, J.H.V. Moisture Absorption in Biodiesel and Its PetroDiesel Blends. Applied Engineering in Agriculture 2007, 23, 71-76.

45. Fazal, M.A.; Haseeb, A.S.M.A.; Masjuki, H.H. Corrosion Mechanism of Copper in Palm Biodiesel. Corrosion Science 2013, 67, 50-59, https://doi.org/10.1016/j.corsci.2012.10.006.

46. Haseeb, A.S.M.A.; Masjuki, H.H.; Ann, L.J.; Fazal, M.A. Corrosion Characteristics of Copper and Leaded Bronze in Palm Biodiesel. Fuel Processing Technology 2010, 91, 329-334, https://doi.org/10.1016/j.fuproc.2009.11.004.

47. McCormick, R.L.; Ratcliff, M.; Moens, L.; Lawrence, R. Several Factors Affecting the Stability of Biodiesel in Standard Accelerated Tests. Fuel Processing Technology 2007, 88, 651-657, https://doi.org/10.1016/j.fuproc.2007.01.006.

48. Pullen, J.; Saeed, K. An Overview of Biodiesel Oxidation Stability. Renewable and Sustainable Energy Reviews 2012, 16, 5924-5950, https://doi.org/10.1016/j.rser.2012.06.024.

49. El-Araby, R.; Amin, A.; El Morsi, A.K.; El-Ibiari, N.N.; El-Diwani, G.I. Study on the Characteristics of Palm Oil-Biodiesel-Diesel Fuel Blend. Egyptian Journal of Petroleum 2017, https://doi.org/10.1016/j.ejpe.2017.03.002.

50. Pasqualino, J.C.; Montané, D.; Salvadó, J. Synergic Effects of Biodiesel in the Biodegradability of FossilDerived Fuels. Biomass and Bioenergy 2006, 30, 874-879, https://doi.org/10.1016/j.biombioe.2006.03.002.

51. Procópio, L. The Role of Biofilms in the Corrosion of Steel in Marine Environments. World J Microbiol Biotechnol 2019, 35, 73, https://doi.org/10.1007/s11274-019-2647-4.

52. Kalnaowakul, P.; Xu, D.; Rodchanarowan, A. Accelerated Corrosion of 316L Stainless Steel Caused by Shewanella Algae Biofilms. ACS Appl. Bio Mater. 2020, 3, 2185-2192, https://doi.org/10.1021/acsabm.0c00037. 